\title{
How Does Strategic Competition Affect Firm Values? A Study of New Product Announcements
}

\author{
Sheng-Syan Chen, Kim Wai Ho, Kueh Hwa Ik, and Cheng-few Lee*
}

\begin{abstract}
We examine the role of strategic interaction in explaining the valuation effect of new product announcements and employ Sundaram, John, and John's (1996) competitive strategy measure to operationalize the nature of a firm's competitive interaction. Using a sample of new product introductions between 1991 and 1995, we find that the market values introductions announced by firms in strategic substitutes competition more favorably than those announced by firms in strategic complements competition. These results hold after we control for other variables that could explain the announcement effect. We also find that industry rivals of those announcing firms that compete in strategic substitutes and experience a positive announcement effect generally suffer a small, but significant wealth loss. The evidence supports the notion that the nature of competitive interaction in an industry is important in assessing the effect of corporate product strategies on shareholder value.
\end{abstract}

Previous studies show that announcements of new product strategies are generally associated with a positive effect on shareholder value (Woolridge, 1988; Chaney, Devinney, and Winer, 1991; Kelm, Narayanan, and Pinches, 1995; and Chen and Ho, 1997). Chaney et al. (1991) find that the value of a new product announcement is higher for firms in more technologically based industries and for firms that make original- or multiple-product announcements. They find that the value is lower for firms that make frequent product announcements. Chaney et al. (1991) also find that higher short-term interest rates have a negative impact on the value of new product introductions. Kelm et al. (1995) find that the announcement-period returns are negatively related to firm size and industry-wide R\&D intensity and positively related to announcement frequency and industry concentration. Chen and Ho (1997) find that new product strategies by firms with good investment opportunities are generally regarded as worthwhile, and those by firms with poor investment opportunities are not. They find that free cash flow has no explanatory power.

Although these empirical studies on the wealth effect of new product strategies are insightful, they do not consider the impact of competitive interaction in an industry. Bulow, Geanakoplos, and Klemperer (1985), Sundaram, John, and John (1996), and other studies suggest that in situations of imperfect product markets, incomplete contracting, or incomplete information, strategic interaction can affect the outcomes of financial and investment choices. Sundaram et al. (1996) provide the first empirical evidence that the nature of competitive interaction in an industry has a significant impact on individual firms' share-price response to the announcement of R\&D spending. ${ }^{1}$ In this paper, we examine whether strategic interaction can also explain the wealth effects of new product announcements.

New product introductions can create opportunities for differentiation and competitive

${ }^{1}$ The importance of strategic competition is also demonstrated in other areas. For example, Aggarwal and Samwick (1999) find that strategic interactions among firms can explain firms' executive compensation schemes.

The authors wish to thank Murillo Campello, the Editors, an anonymous referee, as well as seminar participants at the 2000 FMA Annual Meeting, the Eighth Pacific Basin Finance, Economics and Accounting, and the Second ADSGM International Conference for helpful comments. Any errors are the authors'. Sheng-Syan Chen and Kim Wai Ho acknowledge funding from National Science Council in Taiwan (NSC89-2416-H155-036) and Nanyang Technological University ( $R G$ 2/98), respectively.

"Sheng-Syan Chen is a Professor at Yuan Ze University in Taiwan. Kim Wai Ho is an Associate Professor at Nanyang Technological University in Singapore. Kueh Hwa Ik is a Group Financial Controller at Unza Group of Companies in Singapore. Cheng-few Lee is a Distinguished Professor of Finance at Rutgers University.

Financial Management $•$ Summer $2002 \cdot$ pages 5 - 22 
advantage, which can have a positive impact on the announcing firms' earnings and shareholder values. However, the actual impact depends on how the rival firms respond. If the rivals accommodate the announcers by staying put, then the expected impact on the announcers' profits and firm values will be positive and that on the rivals' will be negative. Bulow et al. (1985) describe this situation as competition in strategic substitutes.

On the other hand, if the rivals' respond to the announcers' product launches by adopting a matching strategy, then the impact on the announcers' profits would be ambiguous. Although the product innovators can enjoy a temporary competitive advantage, they also incur costs in developing and introducing the new products that imitators do not bear (Mansfield, Schwartz, and Wagner, 1981). By imitating the innovators' actions, the rivals might reduce the competitive advantage enjoyed by the innovators and, thus, share in the profits (D'Aveni, 1994). Under this scenario (referred to as competition in strategic complements), the announcers' wealth changes, resulting from the new product announcements, would be ambiguous and could even be negative.

In this study, we use Sundaram et al.'s (1996) competitive strategy measure (CSM) to operationalize the nature of a firm's competitive interaction. The CSM estimates the responsiveness of a firm's marginal profits to changes in its competitors' revenues. The measure is negative when the competition is in strategic substitutes and positive when the competition is in strategic complements. We use this measure to study the role of strategic interaction in determining the effect of new product announcements on shareholder values.

Although we pursue the same goal as Sundaram et al. (1996), that of examining the effects of competitive interaction on corporate investment decisions, this paper differs from theirs in several respects. First, Sundaram et al. (1996) examine the role of CSM in explaining the announcement effects of R\&D spending. Their sample consists of firms that voluntarily announced plans to increase, decrease, or leave unchanged from their previous fiscal year their company-sponsored R\&D expenditures for the forthcoming fiscal year. Kelm et al. (1995) highlight the importance of examining the valuation effects of specific projects. They also argue that investors employ different criteria in valuing the announcements made during the innovation stage of an R\&D project and the commercialization stage, at which new products are launched. However, although Kelm et al. (1995) show that the determinants of the wealth effects of new product announcements can differ from those of R\&D spending, they do not take into account the impact of competitive interaction in an industry. In this paper, we fill the gap by examining the role of CSM in explaining the wealth effects of specific product announcements, instead of announcements of general increase or decrease in R\&D spending. We provide further evidence on the impact of strategic interaction on the outcomes of corporate investment decisions. ${ }^{2}$

Second, Sundaram et al.'s (1996) sample comprises 125 R\&D announcements by 65 firms, which are mainly in R\&D-intensive industries. The sample comprises 384 new product announcements by 101 firms in 39 industries. Thus, the sample size is much larger, and we cover a broader set of industries. Further, only 21 of the 125 announcements in Sundaram et al.'s (1996) sample are "pure" R\&D announcements; the rest are made simultaneously with announcements related to earnings and/or capital expenditures. Sundaram et al. (1996) must control for these confounding effects in their analysis. We use only "non-confounded" news items on new product introductions.

In this paper, we examine a more comprehensive set of control variables than has been used in previous studies. In particular, we control for the potential impact of the announcing

${ }^{2}$ Woolridge (1988) suggests that R\&D expenditures and specific new product introductions are equally important corporate strategic investment decisions. 
firm's stock of patents, which has not been examined in previous studies on new product introductions. Patents might matter in the announcement effects of new product introductions, especially when considering how competitors react. We expect that new products backed by patents should be more valuable to the announcing firms, since competitors would be less able to come up with a matching response. Recent papers (e.g., Deng, Lev, and Narin, 1999; and Hall, 1999) also show that patent measures can have a significant impact on firm value. The sample period from 1991 to 1995, which is more recent than those in previous studies, ${ }^{3}$ coincides with a period of high patenting activity in the US (Hall, Jaffe, and Trajtenberg, 2001b). Thus, it is important that we control for the patent variable.

The results show that, although the average announcement-period return associated with new product introductions is positive, only those firms that compete in strategic substitutes show a significantly positive announcement effect. The valuation effect for those firms that compete in strategic complements is not significantly different from zero. The regression results show that the announcement effect of a new product introduction is significantly negatively related to the CSM. This finding holds even after we control for other variables that could affect the announcement-period return. We also find that industry rivals of those announcing firms that compete in strategic substitutes and experience a positive announcement effect generally suffer a small, but significant wealth loss. The overall results in this study suggest that the nature of competitive interaction in an industry is an important consideration in assessing the effect of corporate product strategies on firm values.

The remainder of the paper is organized as follows. Section I reviews the literature on the determinants of the wealth effect of new product introductions. Section II describes the sample and presents summary statistics. Section III examines the relation between stock price response and the CSM for the announcing firms; section IV examines this relation for the rivals. Section V concludes.

\section{The Determinants of the Wealth Effect of New Product Introductions}

In this section, we provide a review of the literature on the determinants of the wealth effect of new product introductions.

\section{A. Strategic Competition}

A new product announcement conveys new information about the announcing firm's outlook, and this information shapes investors' perception on its market value. When a firm announces new products, it signals to the market that it creates more opportunities for differentiation and competitive advantage, and, hence, increases its long-term stream of earnings and market share (Chaney et al., 1991; Kleinschmidt and Cooper, 1991; and others). Such benefits in profits and market share should have a positive impact on the announcing firm's share price.

As suggested by Bulow et al. (1985), Sundaram et al. (1996), and others, the actual impact on the firm that introduces the new product depends on how its rival firms respond to the introduction. If the rivals accommodate the announcer by staying put, then the announcer's profits and market share will increase and those of its rivals will suffer a reduction. Bulow et al. (1985) describe this situation as competition in strategic substitutes (SS). Under this scenario, the share-price effect associated with a new product introduction will be positive

${ }^{3}$ For example, Kelm et al.'s (1995) sample period is from 1977 to 1989. 
for the announcer and negative for the rivals.

But perhaps the rivals respond to the announcer's strategy by imitating the new product introduction. In this situation, the profit and market share effects on the product introducer could be ambiguous. Although the product innovator can enjoy a temporary competitive advantage, the firm will also incur costs of developing and introducing the new product that imitators do not bear (Mansfield et al., 1981). The product innovator can also face greater risk and market uncertainty and suffer pricing mistakes (Baldwin and Childs, 1969). D'Aveni (1994) argues that, by imitating the innovator's action, the firm's rivals can enjoy the freerider effects by sharing in the profits, or reduce the competitive advantage granted to the innovator, or both. If this happens, then the profit and share-price effects on the product innovator could be ambiguous and might even be negative. Bulow et al. (1985) describe this situation as competition in strategic complements (SC).

Sundaram et al. (1996) argue that whether or not competition occurs in SS or SC depends on the effects of a firm's moves, not on its competitor's average profits, but its marginal profits. For example, assume that two duopolistic firms, A and B, are in an initial equilibrium prior to the announcement (i.e., both firms have already set marginal revenues equal to marginal costs.) If firm A changes its strategy, it affects its own and firm B's marginal profits. To reach a new equilibrium, both firms would re-optimize based on what happens to their marginal profits. If firm B re-optimizes by competing in SS, then its marginal profits must be decreasing. On the other hand, if firm B re-optimizes by competing in SC, then its marginal profits must be increasing. Thus, the profit (and hence the stock price) outcome depends on the sign of the second (cross-partial) derivative of firm A's profits with respect to its own and firm B's strategic variable.

Sundaram et al. (1996) provide the first empirical test on this idea by constructing a proxy for the second (cross-partial) derivative in the context of R\&D competition. They use net income as a measure of "profit" and revenues as a measure of "quantity", to derive a measure called competitive strategy measure (CSM). If CSM is less than zero, then competition is in SS. If CSM is greater than zero, then competition is in SC. Sundaram et al. (1996) find that the market responds positively to increased R\&D spending in situations in which competition is in SS (i.e., CSM $<0$ ), but the reaction is zero-to-negative when competition is in SC (i.e., $C S M>0$ ).

In this study, we examine whether the $C S M$ has similar explanatory power in explaining the announcement effects of new product introductions.

\section{B. Investment Opportunities}

The availability or lack of investment opportunities can be an important consideration in assessing the value of corporate strategic investments (Lang, Stulz, and Walkling, 1989 and 1991; Szewczyk, Tsetsekos, and Zantout, 1996; and others). Chen and Ho (1997) find support for the investment opportunities hypothesis that new product introductions by firms with good investment opportunities are generally regarded as worthwhile, but those by firms with poor investment opportunities are not. Specifically, Chen and Ho (1997) find a significantly positive relation between a firm's Tobin's $q$, a proxy for the firm's investment opportunities, and its share-price response to a new product announcement.

\section{Free Cash Flow}

The availability or lack of free cash flow can also be an important consideration in 
determining the value-enhancing potential of new product investments. Jensen (1986) argues that managers endowed with free cash flow will invest wastefully, rather than pay it out to shareholders. Chen and Ho (1997) suggest that new product investments might be one such use of this free cash flow. Therefore, the potential agency costs of new product investments can be higher for firms with high free cash flow. On the other hand, new product investments by low-free-cash-low firms increase the chance that the firm will seek new external financing. New external financing provides monitoring, and the firm's willingness to undergo such monitoring can be a favorable signal (Szewczyk et al., 1996). Therefore, the free cash flow theory predicts that the market response to a new product announcement will be inversely related to the firm's level of free cash flow. However, the pecking order theory would seem to suggest the opposite relation. Thus, considering the two theories together, the relation between the firm's level of free cash flow and the product announcement abnormal return would be ambiguous.

\section{Debt Ratio}

Jensen (1986) suggests that researchers can consider a firm's debt ratio as an alternative measure of free cash flow. Firms with more free cash flow choose higher levels of debt in their capital structure as a credible pre-commitment to pay out the excess cash flow, thus lowering the expected costs of free cash flow. Jensen's theory suggests a positive relation between the market response to corporate announcements of investment decisions and the announcing firm's debt ratio. Szewczyk et al. (1996) and Chen and Ho (1997) find evidence that supports this prediction for corporate R\&D expenditures and capital expenditures, respectively. In contrast, Chen and Ho (1997) do not find a significant relation between abnormal return and debt ratio for their sample of product strategies.

\section{E. Firm Size}

Small firms need product innovation to survive in the market, but large firms introduce new products only to stay on top of the market (Porter, 1980; and Chaney et al., 1991). Thus, new products should be more highly valued for small firms than for large firms. In addition, large firms' new product introductions might have less unanticipated information than those of small firms as information production and dissemination is a positive function of firm size (Atiase, 1985; Chaney et al., 1991; Kelm et al., 1995; and others). Therefore, firm size should be inversely related to the market valuation of new product introductions. Kelm et al. (1995) report supporting evidence but Chaney et al. (1991) find mixed support.

\section{F. Technological Opportunities}

Chaney et al. (1991) argue that firms in more technologically based industries have greater technology opportunities and require new product innovations to stay alive. They hypothesize that the value of an innovation should be higher for firms in more technologically based industries. They find some evidence that supports this hypothesis. In contrast, Kelm et al. (1995) argue that investors typically expect new product announcements by firms in R\&D-intensive industries and by firms with high $R \& D$ intensity relative to their industry rivals. Thus, the intensity of the market reaction to announcements by these firms will be smaller. Their results show that investors respond positively to new product announcements 
by firms in less-technology-intensive industries. However, they find that the firm's R\&D intensity is not a significant factor.

\section{G. Patent}

A patent is a temporary legal monopoly granted to inventors for the commercial use of an invention. The potential impact of patents on firm value has received much attention in recent years. Hall (1999) surveys the empirical literature that relates firm value to R\&D and patent measures. She concludes that the market value of a firm is related to its knowledge assets, and that patent measures contain information about this value above and beyond that conveyed by $R \& D$ measures.

Previous studies on the market response to new product introductions have not examined the potential impact of the announcing firm's patents. Patents might be important in explaining the announcement effects, especially when we consider how competitors react. We would expect that new products backed by patents should be more valuable to the product announcing firm, since competitors would be less able to come up with a matching (i.e., strategic complements) response. However, Silverman (1999) highlights that patent data have limitations of their own. Much of a firm's technical knowledge may remain unpatented either because it is unpatentable or because a firm may choose to keep their knowledge private by not patenting an innovation. There is also variation in the economic value embodied in individual patents. Further, patents might not reflect all the protected property rights incorporated in a new product because certain companies, such as software companies, also rely on copyrights and trademarks to protect their property rights.

\section{H. Single- or Multiple-Product Announcements}

Chaney et al. (1991) report that firms introducing multiple products experience more wealth gains than those announcing a single product. Other things being equal, firms introducing more products are likely to have more $R \& D$ expenditures, patented inventions and skilled labor (Acs and Audretsch, 1988). They are also likely to be more competitive in the product market and seize more market share especially when the total market is growing very slowly (Hendricks and Singhal, 1997). Thus, multiple-product announcers can appropriate much of the benefits associated with the new products.

\section{Announcement Frequency}

Chaney et al. (1991) argue that factors that expand the information set available to investors about the product or firm should be negatively related to the size of the market impact seen at the time of product announcement. If a firm has a history of making frequent product announcements, then the information value of a new product announcement is likely to be low. The empirical evidence is mixed. Although Chaney et al. (1991) show that the frequency of new product announcements is negatively related to the announcement-period return, Kelm et al. (1995) find the opposite result.

\section{J. Interest Rates}

Since the cost of capital depends on the level of interest rates, firms are expected to reduce their level of investment as expected interest rates rise. Furthermore, rising interest rates can 
imply a decline in product demand, thereby leading to a reduced cash stream of earnings from the product innovation. Chaney et al. (1991) find that higher risk-free rate of interest has a negative impact on the market reaction to new product introductions.

To summarize, the specification of the complete relation that we test in this study is as follows:

Announcement-period Abnormal Return

$=\beta_{0}+\beta_{1} C S M$

$+\beta_{2}$ Tobin's $q+\beta_{3}$ Free Cash Flow $+\beta_{4}$ Debt Ratio $+\beta_{5}$ Firm Size

$+\beta_{6} R \& D$ Intensity $+\beta_{7}$ High-Technology Industry $+\beta_{8}$ Patent

$+\beta_{9}$ Multiple-Product Announcement $+\beta_{10}$ Announcement Frequency

$+\beta_{11}$ Interest Rate + error term

\section{Sample and Descriptive Statistics}

In this section, we first describe the sample design. Then, we describe how we measure abnormal stock return and operationalize a firm's competitive strategy. The control variables and sample characteristics are then described in detail.

\section{A. Sample Design}

We collect a sample of initial announcements of new product introductions by firms listed on either the New York Stock Exchange (NYSE) or the American Stock Exchange (AMEX) from Dow Jones News Retrieval Service (DJNRS) database over the period from January 1991 to December 1995. The DJNRS database provides news-service articles and selected stories from The Wall Street Journal, Dow Jones News Wire, and Barron's. We select the words and phrases and their synonyms, commonly used to describe new product introductions as keys for a database search routine. Examples are "introduce," "new product," "unveil," "launch," "received approval," "to market," "test market," "begin selling," along with other pertinent words and phrases. We include both new products and product updates as in Chaney et al. (1991). Also, we identify the information on the firms and the products, as well as other information (such as marketing information) from the news contents.

To be included in the final sample, the new product announcements have to meet the following criteria: 1 ) to avoid any confounding events that could distort the measurement of the valuation effects, the announcing firms should not have other announcements five days before and after the initial announcement date; 2) daily stock return information must be available from CRSP (Center for Research in Security Prices); and 3) companies' financial information must be available from the Compustat files. The final sample comprises 384 announcements by 101 companies.

\section{B. Measuring Abnormal Stock Returns}

Standard event-study methods are employed to examine stock price responses to announcements of new product introductions. Day 0 is defined as the initial announcement date. The abnormal return is calculated as the difference between the actual return and an expected return generated by the market model. We use the value weighted CRSP index as a proxy for market returns and estimate the parameters of the market model using the data over a period from 200 to 60 days before the announcement date. The significance tests are conducted using the $t$ statistic as well as the Wilcoxon $z$-statistic. ${ }^{4}$ We use the two-day $(-1,0)$ announcement-period ${ }^{4}$ We also perform significance tests using the $z$-statistic as described in Dodd and Warner (1983) and obtain similar results. 
abnormal return as the dependent variable in the cross-sectional analysis.

\section{Operationalizing a Firm's Competitive Strategy}

We follow Sundaram et al. (1996) to operationalize the nature of a firm's competitive interaction by constructing an empirical competitive strategy measure (CSM). We need three elements to calculate the CSM: 1) the announcing firm's net income, 2) the announcing firm's net sales, and 3) its rivals' net sales, where the net income is a proxy for profit and net sales a proxy for output. The set of rivals are defined as all the firms with the same four-digit primary Standard Industrial Classification (SIC) code in Compustat except the announcing firm (as in Sundaram et al., 1996, and others). We obtain seven years (i.e., 28 quarters) of data on quarterly net income and quarterly net sales, up to and including the quarter prior to the announcement quarter, from Compustat. We measure announcing firm's marginal profit by the ratio of change in its net income $\left(D p^{A}\right)$ to change in its own net sales $\left(D S^{A}\right)$. The $C S M$ is the correlation coefficient between $D p^{A} / D S^{A}$ and the change in the rivals' net sales $\left(D S^{R}\right)$ over the period of 28 quarters prior to the announcement quarter. If the CSM is negative, the competition is in strategic substitutes. If the CSM is positive, the competition is in strategic complements. If the CSM is equal to zero, the competition is in neither strategic substitutes nor strategic complements. ${ }^{5}$

\section{Control Variables}

Data are obtained on the firm and industry characteristics from the Compustat files. We estimate investment opportunities $(Q)$ by a simple measure of Tobin's $q$ : the ratio of the market to book value of the firm's assets, where the market value of assets equals the book value of assets minus the book value of common equity plus the market value of common equity. This measure is widely used in previous studies, such as Denis (1994), Perfect and Wiles (1994), Barclay and Smith (1995a and 1995b), Chen and Ho (1997), and Holderness, Kroszner, and Sheehan (1999). ${ }^{6}$ The $q$ variable is the average $q$ ratio for the three fiscal years prior to the announcement, which is similar to that used in Lang et al. (1989 and 1991), Szewczyk et al. (1996), and Chen and Ho (1997). A three-year average gives a better estimate of a firm's true $q$ (Lang et al., 1989). We regard high- $q$ firms as firms with good investment opportunities and low- $q$ firms as firms with poor investment opportunities.

Free cash flow $(F C F)$ is defined as operating income before depreciation minus interest expense, taxes, preferred dividends, and common dividends, divided by book value of total assets, for the fiscal year prior to the announcement (as in Lehn and Poulsen, 1989; Lang et al., 1991; and others). Debt ratio (DEBT RATIO) is the book value of total debt divided by the book value of total equity for the fiscal year prior to the announcement. ${ }^{7}$ The firm size variable (SIZE) is the logarithm of book value of total assets for the fiscal year prior to the announcement. ${ }^{8}$

A firm's R\&D intensity $(R D I)$ is defined as the intensity of the firm's $R \& D$ effort $(R \& D$ per

${ }^{5}$ The CSM should be a measure of how an announcing firm's rivals behave. However, as noted by Sundaram et al. (1996), due to data difficulties in identifying competitor profits, the actually implemented CSM is a measure of how the announcing firm itself behaves. Sundaram et al. (1996) argue that firms' strategies to compete can reasonably be assumed to be symmetric.

${ }^{6}$ Other studies, such as Lang et al. (1989 and 1991), use the theoretical Tobin's $q$ (defined as the ratio of the market value of a firm to the replacement costs of its assets) as a proxy for investment opportunities. Because of data availability, we use this simple measure of $q$. Chung and Pruitt (1994) show that at least $96.6 \%$ of the variability of Tobin's $q$ is explained by this simple measure of $q$.

${ }^{7}$ We obtain similar results when we measure debt ratio as the book value of total debt to the book value of total assets.

${ }^{8}$ The results are similar when we use market capitalization to measure firm size. 
dollar of net sales) divided by its industry's for the fiscal year prior to the announcement (as in Kelm et al. 1995). We use a dummy variable (HILO), which equals one if the announcing firm is in a high-technology industry and zero otherwise, as a proxy for technology opportunities at the industry level (as in Chan, Martin, and Kensinger, 1990). We can classify 281 announcements as those made by firms in high-technology industries.

We measure a firm's stock of patents (PATENT) by the depreciated patent stock of the firm in the year of announcement. ${ }^{9}$ Following Hall, Jaffe, and Trajtenberg (2000), we use a declining balance formula and a depreciation rate of $15 \%$ as follows: $P S_{t}=0.85 P S_{t-1}+P_{t}$, where $P S_{t}$ is the patent stock in year $t$, and $P_{t}$ is the number of patent applications in year $t$ that are ultimately granted. We do not have patent information for individual products because new product announcements do not normally mention the patents embodied in the products. We use the announcing firm's patent count as our measure because it has been widely used as a proxy for a firm's technological assets (Deng et al., 1999; Hall, 1999; McGahan and Silverman, 2001; and others).

The patent data are obtained from the recently available NBER patents citations data file (Hall, Jaffe, and Trajtenberg, 2001a)..$^{10}$ The NBER patents data are for the years from 1967 to 1996. Hall et al. (2000) discuss the potential truncation bias in the patent measures using the NBER patents data file because of the time lag between the application date and the grant date, which is typically about 2 years. Thus, the number of patent applications in the last few years of the NBER data file could be understated because of missing observations consisting of patents that may have been applied for but not yet been granted. Since the sample period extends from 1991 to 1995, the patent stocks of firms that made new product announcements in the later years in the sample period could be understated. ${ }^{11}$

We create a dummy variable, MULTIPLE, which equals one for multiple-product announcements and zero for single-product announcements (as in Chaney et al. 1991). There are 121 multiple-product announcements in the sample. We determine the announcement frequency $(F R E Q)$ by the number of new product announcements made by an announcing firm within 12 months prior to the announcement date. ${ }^{12}$ The interest rate variable (INTEREST) is the average of 90-day Treasury bill rates for the announcement year (as in Chaney et al, 1991). These data are obtained from the US Department of Commerce. ${ }^{13}$

${ }^{9}$ The results are unchanged when we use the firm's depreciated patent stock in the year prior to the announcement. Also, we use a dummy variable that equals one if PATENT is greater than the sample median, and zero otherwise. The results are similar.

${ }^{10}$ The authors are grateful to Bronwyn $\mathrm{H}$. Hall for generously sharing her clean data set with us.

${ }^{11} \mathrm{Hall}$ et. al. (2000) also discuss the truncation problem in their citation-adjusted patent measures because of the long citation lag between patent applications and subsequent patent citations. This problem is more acute in the sample because the sample period falls in the last few years of the NBER patents data file. Because of this problem, we do not use citation-adjusted patent stock as our variable.

${ }^{12}$ The results are similar when we measure announcement frequency by the number of new product announcements over the 5-year sample period of the study, which is similar to the measure used by Chaney et al. (1991) and Kelm et al. (1995).

${ }^{13}$ We also examine the significance of several other control variables used in previous studies: year dummies, the announcing firm's systematic risk (beta), product newness, entry timing, industry concentration, and industry $R \& D$ intensity. We estimate beta using daily stock returns and the CRSP value-weighted market returns for days -200 to -60 . Product newness is one if the product is a high-newness product, and zero if it is an update (as in Chaney et al., 1991). Entry timing equals one if the announcing firm is the first mover, and zero otherwise (as in Lee, 1995). Industry concentration is measured by the Herfindahl index, which is the sum of the squared fraction of industry sales by all firms in the 4-digit SIC industry for the fiscal year prior to the announcement (as in Hendricks and Singhal, 1997). Industry R\&D intensity is defined as the R\&D expenditures by all firms in the 4-digit SIC industry divided by industry net sales (as in Kelm et al., 1995). We find that these additional control variables have no significant explanatory power and that the conclusions in this study remain unchanged. These results are available upon request. 


\section{E. Sample Characteristics}

Table I presents sample distributions by year, summary statistics, and announcementperiod abnormal returns. Panel A shows that the sample is roughly evenly distributed across years except for 1995, which accounts for $31 \%$ of the sample. Panel B presents summary statistics for the CSM and several control variables used in this study. The mean (median) $C S M$ in the sample of new product introductions is $0.04(0.06)$, indicating that the average sample firm competes in strategic complements. ${ }^{14}$ In contrast, the average (median) CSM of -0.02 (-0.02) in Sundaram et al.'s (1996) sample of R\&D spending implies that their average sample firm competes on the basis of strategic substitutes. There is also considerable crosssectional variation in the CSM in the sample. The standard deviation is 0.18 and the range is 0.75 (from -0.28 to 0.47$)$. Panel $\mathrm{C}$ shows that for the overall sample, the two day $(-1,0)$ average and median cumulative abnormal returns for the firms announcing new product introductions are, respectively, $0.59 \%$ and $0.28 \%$, both significant at the $1 \%$ level. Thus, shareholders of the sample firms on average experience significant wealth gains from new product investments similar to those found by Woolridge (1988), Chaney et al. (1991), Kelm et al. (1995), and Chen and Ho (1997).

We also investigate the average $C S M$ for each industry in the sample as shown in Table II. The industry average CSM ranges from -0.28 (computer peripherals) to +0.47 (plastic materials and synthetics). However, as noted by Sundaram et al. (1996), interpretation of this industry classification is limited because many of the industries have small sample sizes.

\section{Stock Price Response for the Announcing Firms and the CSM}

In this section, we investigate stock price response for the announcing firms and the CSM. First, we analyze subgroups based on CSM. Then, the cross-sectional regression analyses are studied in detail.

\section{A. Analysis of Subgroups Based on the CSM}

In Table III, the sample is divided into three subgroups based on the CSM: 1) firms competing in strategic substitutes (SS), 2) firms competing in strategic complements (SC), and 3) firms competing on the basis of neither strategic substitutes nor complements. In Panel A, Sundaram et al.'s (1996) classification method is followed by defining the SS group as the sample firms with CSM values less than -0.05 , the SC group as those with CSM values greater than 0.05, and the neither-SS-nor-SC group as those with CSM values falling within \pm 0.05 . The results in Panel A show that the SS group experiences a significantly positive mean announcement effect $(0.87 \%)$. The mean announcement effect of the SC group is positive $(0.23 \%)$ but insignificant. The mean difference in abnormal returns between the SS and the SC groups is $0.64 \%$ and is significant at the $5 \%$ level using a one-tailed test. This result is robust to possible deviations from nonnormality, since it also holds for the nonparametric Kruskal-Wallis test statistic. Note that the distinction between the SS and the SC groups is obscured by the neither-SS-nor-SC group, which experiences a significantly positive announcement effect.

To test the robustness of the results, we also use \pm 0.04 and \pm 0.03 as the cut-off CSM values to define the three subgroups. ${ }^{15}$ We report the results in Table III, Panels B and C, respectively. The results in Panel B are similar to those in Panel A. In Panel C, the results are

${ }^{14} 227$ firms in the sample have $C S M>0$ and 157 firms have $C S M<0$.

${ }^{15}$ We have also used $\pm 0.02, \pm 0.01$, and 0.00 as the cut-off $C S M$ values in the sensitivity analysis. The conclusions in the study remain unchanged. 


\section{Table I. Sample Distribution, Summary Statistics, and Announcement-Period} Abnormal Returns

This table presents sample distribution by year, summary characteristics for the competitive strategy measure (CSM), and for the several control variables used in this study, and the announcement-period abnormal returns. Our sample comprises 384 new product announcements made between 1991 and 1995 by 101 firms listed on either the NYSE or AMEX. This sample is collected from the Dow Jones News Retrieval Service (DJNRS) database. In Panel B, CSM is defined as the coefficient of correlation between: a) ratio of change in firm's quarterly net income to change of firm's quarterly net sales and b) change in the rest-of-industry's quarterly net sales, over the period of 28 quarters prior to announcement quarter. Tobin's $q$ is the average ratio of the market value of assets to the book value of the firm's assets for the three fiscal years before the announcement, where the market value of assets equals the book value of assets minus the book value of common equity plus the market value of common equity. Free cash flow is defined as operating income before depreciation minus interest expense, taxes, preferred dividends, and common dividends, divided by book value of total assets, for the fiscal year prior to the announcement. Debt ratio is the book value of total debt divided by the book value of total equity for the fiscal year prior to the announcement. Firm size is the book value of total assets for the fiscal year prior to the announcement. R\&D intensity is the intensity of the firm's R\&D effort (R\&D per dollar of net sales) divided by its industry's for the fiscal year prior to the announcement. Patent stock is the stock of patents of the announcing firm in the year of the announcement. Announcement frequency is the number of new product announcements made by an announcing firm within 12 months prior to the announcement date. We measure interest rate by the average of 90-day Treasury bill rates for the announcement year. In Panel C, two-day $(-1,0)$ announcement-period abnormal returns are estimated for the firms that announce new product introductions, using the standard market model procedure with parameters estimated for the period 200 days to 60 days before the announcement. Data are obtained from the DJNRS database, the CRSP and Compustat files, and the US Department of Commerce.

\begin{tabular}{lcc}
\hline \hline \multicolumn{3}{c}{ Panel A. Sample Distribution by Year } \\
\hline $\bar{Y}$ Year & No. of Announcements & \% of Sample \\
\cline { 2 - 3 } 1991 & 67 & 17.5 \\
1992 & 49 & 12.8 \\
1993 & 78 & 20.3 \\
1994 & 72 & 18.8 \\
1995 & 118 & 30.6 \\
Total & 384 & 100.0 \\
\hline \hline
\end{tabular}

\begin{tabular}{|c|c|c|c|}
\hline \multicolumn{4}{|c|}{ Panel B. Summary Statistics } \\
\hline Variables & Mean & Median & $\begin{array}{l}\text { Standard } \\
\text { Deviation }\end{array}$ \\
\hline Competitive Strategy Measure & 0.04 & 0.06 & 0.18 \\
\hline Tobin's $q$ & 1.76 & 1.44 & 0.94 \\
\hline Free Cash Flow & 0.08 & 0.09 & 0.05 \\
\hline Debt Ratio & 0.91 & 0.62 & 1.49 \\
\hline Firm Size (\$ millions) & 8,341 & 10,509 & 5,928 \\
\hline R\&D Intensity & 1.02 & 0.93 & 0.54 \\
\hline Patent Stock & 1,142 & 372 & 1,598 \\
\hline Announcement Frequency & 1.93 & 1.00 & 2.42 \\
\hline Interest Rate & 0.05 & 0.04 & 0.01 \\
\hline \multicolumn{4}{|c|}{ Panel C. Two-Day Announcement-Period Abnormal Returns of Announcers } \\
\hline \multirow{4}{*}{\multicolumn{2}{|c|}{$\begin{array}{l}\text { Mean } \\
t \text {-statistic } \\
\text { Median } \\
p \text {-value for the Wilcoxon } z \text {-statistic }\end{array}$}} & \multicolumn{2}{|c|}{$0.59 \%$} \\
\hline & & \multicolumn{2}{|c|}{$2.57 * * *$} \\
\hline & & \multicolumn{2}{|c|}{$0.28 \%$} \\
\hline & & \multicolumn{2}{|c|}{0.002} \\
\hline
\end{tabular}

***Significant at the 0.01 level, using a two-tailed test. 
Table II. Average Industry Competitive Strategic Measure

This table presents the average industry competitive strategic measure (CSM) for 384 new product announcements made by 101 different firms from 39 industries during the 1991 to 1995 period. Each industry group is defined as all the firms with the same four-digit primary SIC code in Compustat. CSM is measured by the coefficient of correlation between: a) ratio of change in firm's quarterly net income to change of firm's quarterly net sales and b) change in the rest-of-industry's quarterly net sales, over the period of 28 quarters prior to announcement quarter. A negative correlation indicates strategic substitutes, and a positive correlation indicates strategic complements.

\begin{tabular}{|c|c|c|c|}
\hline Industry & $\begin{array}{c}\text { No. of } \\
\text { Announcements }\end{array}$ & $\begin{array}{c}\% \text { of } \\
\text { Sample }\end{array}$ & $\begin{array}{c}\text { Average } \\
\text { CSM }\end{array}$ \\
\hline Food and Kindred Products (2000) & 4 & 1.04 & 0.03 \\
\hline Grain Mills Products (2040) & 4 & 1.04 & -0.19 \\
\hline Sugar and Confectionery Products (2060) & 4 & 1.04 & -0.08 \\
\hline Beverages (2080) & 16 & 4.17 & 0.08 \\
\hline Paper Mills (2621) & 4 & 1.04 & 0.09 \\
\hline Misc. Converted Paper Products (2670) & 6 & 1.56 & 0.09 \\
\hline Newspaper (2711) & 14 & 3.65 & 0.19 \\
\hline Chemicals and Allied Products (2800) & 3 & 0.78 & -0.04 \\
\hline Plastics Materials and Synthetics (2820) & 2 & 0.52 & 0.47 \\
\hline Plastics Materials and Resins (2821) & 2 & 0.52 & -0.13 \\
\hline Pharmaceuticals Preparations (2834) & 54 & 14.06 & 0.02 \\
\hline Diagnostics Substances (2835) & 2 & 0.52 & 0.26 \\
\hline Toilet Preparations (2844) & 1 & 0.26 & 0.13 \\
\hline Petroleum Refining (2911) & 6 & 1.56 & -0.08 \\
\hline Misc. Nonmetallic Mineral Products (3290) & 3 & 0.78 & -0.17 \\
\hline Cutlery, Handtools and Hardware (3420) & 5 & 1.30 & 0.15 \\
\hline Computer and Office Equipment (3570) & 74 & 19.27 & 0.11 \\
\hline Electronic Computer (3571) & 29 & 7.55 & 0.00 \\
\hline Computer Storage Devices (3572) & 2 & 0.52 & 0.13 \\
\hline Computer Peripherals (3577) & 2 & 0.52 & -0.28 \\
\hline Calculating/Accounting Equipment (3578) & 1 & 0.26 & -0.15 \\
\hline Office Machines (3579) & 2 & 0.52 & -0.02 \\
\hline Electronic/Other Elect. Equipment (3600) & 20 & 5.21 & -0.03 \\
\hline Household Audio/Video Equipment (3651) & 16 & 4.17 & 0.09 \\
\hline Telephone and Telegraph Apparatus (3661) & 5 & 1.30 & -0.09 \\
\hline Radio/TV Communication Equip. (3663) & 14 & 3.65 & 0.11 \\
\hline Semiconductors (3674) & 7 & 1.83 & -0.12 \\
\hline Motor Vehicles and Car Bodies (3711) & 19 & 4.95 & 0.03 \\
\hline Motor Vehicles Parts (3714) & 1 & 0.26 & 0.07 \\
\hline Aircraft $(3721)$ & 1 & 0.26 & -0.06 \\
\hline Guided Missiles (3760) & 1 & 0.26 & -0.17 \\
\hline Instruments and Related Products (3825) & 1 & 0.26 & -0.18 \\
\hline Surgical and Medical Instruments (3841) & 2 & 0.52 & -0.11 \\
\hline Electromedical Equipment (3845) & 7 & 1.83 & -0.05 \\
\hline Ophthalmic Goods (3851) & 3 & 0.78 & 0.06 \\
\hline Photographic Equipment/Supplies (3861) & 21 & 5.47 & 0.14 \\
\hline Telephone Communication not Radio (4813) & 23 & 5.99 & -0.06 \\
\hline Hotels and Motels (7011) & 2 & 0.52 & 0.01 \\
\hline Motion Pictures and Video Production (7819) & 1 & 0.26 & 0.28 \\
\hline Total & 384 & 100.00 & 0.04 \\
\hline
\end{tabular}


Table III. Average Announcement-Period Abnormal Returns of Announcers Stratified by the Competitive Strategy Measure

This table presents the two-day $(-1,0)$ average announcement-period abnormal returns for the firms that announce new product introductions, classified by the competitive strategy measure (CSM). We estimate the announcement-period abnormal returns using the standard market model procedure with parameters estimated for the period 200 days to 60 days before the announcement. CSM is measured by the coefficient of correlation between: a) ratio of change in firm's quarterly net income to change of firm's quarterly net sales and b) change in the rest-of-industry's quarterly net sales, over the period of 28 quarters prior to announcement quarter. In Panel A, strategic substitutes (SS) firms are defined as those with $C S M<-0.05$, strategic complements (SC) firms as those with $C S M>+0.05$, and firms that are neither SS nor SC as those with $-0.05 \leq C S M \leq+0.05$. In Panels B and C, \pm 0.04 and \pm 0.03 are used as cut-off values, respectively. For each cell, we report the mean abnormal return and, in parentheses, the $t$-statistic and the number of observations. For comparison of means, we report the mean difference and, in parentheses, the $t$-statistic assuming unequal variances and the $p$-value for the nonparametric Kruskal-Wallis statistic. The results are similar with the assumption of equal variances.

\begin{tabular}{lccc}
\hline \hline $\begin{array}{l}\text { Strategic } \\
\text { Substitutes (SS) }\end{array}$ & $\begin{array}{c}\text { Neither SS } \\
\text { Nor SC }\end{array}$ & $\begin{array}{c}\text { Strategic } \\
\text { Complements (SC) }\end{array}$ & $\begin{array}{c}\text { Mean Difference } \\
\text { (SS - SC) }\end{array}$ \\
\hline \hline & \multicolumn{1}{c}{ Panel A. Cut-Off Values $= \pm 0.05$} & \\
\hline \hline $0.87 \%$ & $1.12 \%$ & $0.23 \%$ & $0.64 \%$ \\
$\left(3.03^{* * *}, 127\right)$ & $\left(2.43^{* * *}, 56\right)$ & $(1.23,201)$ & $\left(1.84^{* *}, 0.05\right)$ \\
\hline \hline \multicolumn{4}{c}{ Panel B. Cut-Off Values $= \pm 0.04$} \\
\hline \hline $0.96 \%$ & $0.62 \%$ & $0.25 \%$ & $0.71 \%$ \\
$\left(3.14^{* * *}, 133\right)$ & $\left(1.66^{* *}, 45\right)$ & $(1.42,206)$ & $\left(1.97^{* *}, 0.04\right)$ \\
\hline \hline $0.95 \%$ & Panel C. Cut-Off Values $= \pm 0.03$ & $0.66 \%$ \\
$\left(3.20^{* * *}, 137\right)$ & $0.46 \%$ & $0.29 \%$ & $\left(1.92^{* *}, 0.05\right)$ \\
\hline \hline
\end{tabular}

*** Significant at the 0.01 level, using a one-tailed test.

**Significant at the 0.05 level, using a one-tailed test.

also similar to those in Panels A and B, except that the announcement effect for the neitherSS-nor-SC group becomes insignificant.

In summary, the results in Table III generally support the theoretical predictions for the role of strategic competition in explaining the wealth effect of new product announcements. The announcement effect on the share prices for the announcing firms competing in strategic substitutes is significantly positive, but for those competing in strategic complements, the announcement-period return is not significant. Further, the announcement effect is significantly more favorable for the announcing firms competing in strategic substitutes than for those competing in strategic complements.

\section{B. Cross-Sectional Regression Analyses}

Table IV presents cross-sectional regression analyses of the announcement-period abnormal returns for the sample against the CSM and control variables. Model 1 includes the $C S M$ as the only explanatory variable. Model 2 includes only the control variables, but excluding PATENT. Model 3 includes all the control variables. Model 4 combines Models 1 and 2, and Model 5 combines Models 1 and 3. The $t$-values are computed with heteroskedasticity-consistent standard errors (White, 1980). The number of observations varies because of data unavailability. 
Table IV. Regressions of Announcement-Period Abnormal Returns

This table presents regression analyses of the two-day $(-1,0)$ announcement-period abnormal returns for the firms that announce new product introductions against the competitive strategy measure $(C S M)$ and control variables. The announcement-period abnormal returns is estimated using the standard market model procedure with parameters estimated for the period 200 days to 60 days before the announcement. CSM is measured by the coefficient of correlation between: a) ratio of change in firm's quarterly net income to change of firm's quarterly net sales and b) change in the rest-of-industry's quarterly net sales, over the period of 28 quarters prior to announcement quarter. $Q$ is the average ratio of the market value of assets to the book value of the firm's assets for the three fiscal years before the announcement, where the market value of assets equals the book value of assets minus the book value of common equity plus the market value of common equity. $F C F$ is the operating income before depreciation minus interest expense, taxes, preferred dividends, and common dividends, divided by book value of total assets, for the fiscal year prior to the announcement. DEBT RATIO is the book value of total debt divided by the book value of total equity for the fiscal year prior to the announcement. SIZE is the logarithm of book value of total assets for the fiscal year prior to the announcement. $R D I$ is the intensity of the firm's R\&D effort (R\&D per dollar of net sales) divided by its industry's for the fiscal year prior to the announcement. HILO equals one if the announcing firm is in a high-technology industry, and zero otherwise. PATENT is the stock of patents of the announcing firm in the year of the announcement. MULTIPLE equals one for multiple-product announcements, and zero for single-product announcements. $F R E Q$ is the number of new product announcements made by an announcing firm within 12 months prior to the announcement date. INTEREST is the average of 90-day Treasury bill rates for the announcement year. We compute the $t$-value in parentheses using heteroskedasticity-consistent standard errors (White, 1980). The number of observations varies across regressions because of data unavailability.

\begin{tabular}{|c|c|c|c|c|c|}
\hline \multirow{2}{*}{$\begin{array}{l}\text { Independent } \\
\text { Variables }\end{array}$} & \multicolumn{5}{|c|}{ Models } \\
\hline & 1 & 2 & 3 & 4 & 5 \\
\hline \multirow[t]{2}{*}{ INTERCEPT } & 0.218 & 1.135 & 1.334 & 1.15 & 1.441 \\
\hline & $(3.81) * * *$ & $(1.74)^{*}$ & $(1.83)^{*}$ & $(1.78)^{*}$ & $(2.00)^{* *}$ \\
\hline \multirow[t]{2}{*}{ CSM } & -0.584 & & & -0.687 & -0.577 \\
\hline & $(-2.02) * *$ & & & $(-2.14) * *$ & $(-1.75)^{*}$ \\
\hline \multirow[t]{2}{*}{$Q$} & & 0.205 & 0.237 & 0.197 & 0.229 \\
\hline & & $(2.82)^{* * *}$ & $(2.75)^{* * *}$ & $(2.73)^{* * *}$ & $(2.66) * * *$ \\
\hline \multirow[t]{2}{*}{$F C F$} & & -0.020 & -0.024 & -0.023 & -0.028 \\
\hline & & $(-1.65)^{*}$ & $(-1.72)^{*}$ & $(-1.75)^{*}$ & $(-1.96)^{* *}$ \\
\hline \multirow[t]{2}{*}{ DEBT RATIO } & & 0.050 & 0.051 & 0.041 & 0.038 \\
\hline & & $(1.22)$ & $(1.11)$ & $(0.95)$ & $(0.82)$ \\
\hline \multirow[t]{2}{*}{$S I Z E$} & & -0.109 & -0.141 & -0.109 & -0.148 \\
\hline & & $(-2.36) * *$ & $(-2.58) * * *$ & $(-2.34) * *$ & $(-2.74) * * *$ \\
\hline \multirow[t]{2}{*}{$R D I$} & & 0.330 & 0.307 & 0.321 & 0.300 \\
\hline & & $(2.45)^{* *}$ & $(2.28)^{* *}$ & $(2.34) * *$ & $(2.28)^{* *}$ \\
\hline \multirow[t]{2}{*}{ HILO } & & -0.038 & -0.105 & -0.078 & -0.143 \\
\hline & & $(-0.25)$ & $(-0.58)$ & $(-0.50)$ & $(-0.79)$ \\
\hline \multirow[t]{2}{*}{ PATENT } & & & 0.000 & & 0.000 \\
\hline & & & $(0.69)$ & & $(0.96)$ \\
\hline \multirow[t]{2}{*}{ MULTIPLE } & & 0.019 & 0.015 & 0.071 & 0.063 \\
\hline & & $(0.15)$ & $(0.11)$ & $(0.54)$ & $(0.46)$ \\
\hline \multirow[t]{2}{*}{ FREQ } & & 0.021 & 0.019 & 0.023 & 0.019 \\
\hline & & $(2.48)^{* *}$ & $(1.78)^{*}$ & $(2.83) * * *$ & $(1.82)^{*}$ \\
\hline \multirow[t]{2}{*}{ INTEREST } & & -0.167 & -0.148 & -0.158 & -0.142 \\
\hline & & $(-2.75) * * *$ & $(-2.36)^{* *}$ & $(-2.65) * * *$ & $(-2.29) * *$ \\
\hline$N$ & 384 & 329 & 288 & 329 & 288 \\
\hline Adjusted $R^{2}$ & 0.007 & 0.078 & 0.083 & 0.086 & 0.087 \\
\hline$F$-value & $3.51 *$ & $4.17 * * *$ & $3.59 * * *$ & $4.18 * * *$ & $3.49 * * *$ \\
\hline
\end{tabular}


Model 1 shows that the CSM is significantly negatively related to the announcing firms' cumulative abnormal returns. The result is again consistent with the theoretical prediction that the announcement effect is more favorable for firms competing in strategic substitutes than for those competing in strategic complements.

Models 2 and 3 show that several control variables are significant in explaining the wealth effect associated with new product introductions. The announcement-period abnormal returns are significantly positively related to the announcing firm's investment opportunities $(Q), \mathrm{R} \& \mathrm{D}$ intensity $(R D I)$, and announcement frequency $(F R E Q)$, and are significantly negatively related to the announcing firm's free cash flow $(F C F)$, size (SIZE), as well as interest rates (INTEREST). These relations are consistent with the theoretical predictions in the literature except for announcement frequency and the announcing firm's R\&D intensity, where the expected relation is negative. Chaney et al. (1991) suggest that the information content of a new product announcement is likely to be low when a firm has a history of making frequent product announcements. However, we find that announcements by frequent announcers are associated with higher abnormal returns than those of less frequent announcers. This result, which is similar to the finding in Kelm et al. (1995), is consistent with the notion that frequent announcers are able to capitalize on follow-on investment projects and generate future investment opportunities. ${ }^{16}$ With regard to the firm's R\&D intensity, Kelm et al. (1995) argue that the market reaction to announcements by firms with high $R \& D$ intensity relative to their rivals should be smaller because investors typically expect new product announcements by these firms. However, they do not find significant results in their study. In contrast, the market values those products that are announced by firms with high R\&D intensity more highly. This evidence is consistent with the view that $R \& D$ spending is an important source of intangible capital and product differentiation (Chauvin and Hirschey, 1993; and others). The combined results on announcement frequency and the firm's R\&D intensity suggest that the market places a significant premium on new products rolled out by firms that are known to be leaders in product innovations and in creating valuable follow-on technological opportunities.

We do not find a significant relation between abnormal return and DEBT RATIO. This result is similar to the finding in Chen and Ho (1997). We also find that HILO and PATENT are not significant. The single-/multiple-product (MULTIPLE) dummy variable is also not significant. In contrast, Chaney et al. (1991) find some evidence of more favorable market reactions to announcements of multiple products.

Models 4 and 5 show that the CSM is still significantly negatively related to the announcing firms' cumulative abnormal returns when we include the control variables in the regression. The relations between the announcement effect and the control variables remain unchanged. The overall results in Table IV support the notion that the nature of competitive interaction in an industry is an important consideration in assessing the wealth effect of corporate product strategies.

\section{Stock Price Response for Industry Rivals and the CSM}

We also examine the two-day $(-1,0)$ announcement-period abnormal returns for the rival firms pooled into an equally weighted portfolio that have the same four-digit primary SIC

\footnotetext{
${ }^{16}$ Smit and Ankum (1993) suggest that an investment strategy can encompass a sequence of tactical investment projects, of which several may yield a low return when considered in isolation, but they are valuable in generating options to invest in follow-on projects for future commercial exploitation. Kasanen (1993) also suggests that firms can create value by "spawning" investment opportunities and that a collection of projects linked together through cross-spawning can be worth more than the sum of the individual projects.
} 
Table V. Industry Rivals' Average Abnormal Returns over the Announcement Period

This table presents the two-day $(-1,0)$ average announcement-period abnormal returns for industry rivals pooled into an equally weighted portfolio that have the same four-digit SIC code in Compustat. The announcement-period abnormal returns is estimated using the standard market model procedure with parameters estimated for the period 200 days to 60 days before the announcement. Since competitor returns data are unavailable for 21 announcements, the size of the total competitor sample is reduced to 363. Panel A shows the results for the total rival sample. Panel B classifies the rivals' announcement period abnormal returns by the competitive strategy measure (CSM) and the own-firm announcement effect $(F C A R)$. CSM is measured by the coefficient of correlation between: a) ratio of change in firm's quarterly net income to change of firm's quarterly net sales and b) change in the restof-industry's quarterly net sales, over the period of 28 quarters prior to announcement quarter. We define the SS group as CSM $<0$ and the SC group as $C S M \geq 0$. For each cell, we report the mean abnormal return and, in parentheses, the $t$-statistic and the number of observations.

\begin{tabular}{|c|c|c|}
\hline \multicolumn{3}{|c|}{ Panel A. Total Rival Sample } \\
\hline Average Abnormal Return & $t$-Statistic & $N$ \\
\hline$-0.15 \%$ & $-2.23 * *$ & 363 \\
\hline \multicolumn{3}{|c|}{$\begin{array}{c}\text { Panel B. Analysis of Subsamples Stratified According to the CSM and Announcers' Cumulative } \\
\text { Abnormal Returns (FCAR) }\end{array}$} \\
\hline & $\begin{array}{c}\text { Strategic } \\
\text { Substitutes (SS) }\end{array}$ & $\begin{array}{c}\text { Strategic } \\
\text { Complements (SC) }\end{array}$ \\
\hline & $\begin{array}{c}-0.21 \% \\
(-1.87 * *, 85)\end{array}$ & $\begin{array}{c}-0.07 \% \\
(-0.62,129)\end{array}$ \\
\hline$F C A R<0$ & $\begin{array}{c}-0.13 \% \\
(-0.96,52)\end{array}$ & $\begin{array}{l}-0.21 \% \\
(-1.49,97)\end{array}$ \\
\hline
\end{tabular}

** Significant at the 0.05 level, using a one-tailed test.

code in Compustat (as in Sundaram et al., 1996). Table V presents the results. Since competitor returns data are unavailable in the case of 21 announcements, the size of the total competitor sample is reduced to 363. Panel A shows that, on average, industry rivals experience a small but significantly negative abnormal return of $-0.15 \%$ for the two-day announcement-period. The results suggest that for the sample as a whole, industry rivals suffer wealth loss when announcing firms introduce new products.

In Panel B, we further classify the rivals' announcement-period abnormal returns by the $C S M$ and the own-firm announcement effect (FCAR), where we follow Sundaram et al.'s (1996) classification method by defining the SS group as $C S M<0$ and the SC group as $C S M \geq 0 .{ }^{17}$ When the competition is in strategic substitutes and when announcing firm's abnormal return is positive, the rivals experience a significant average loss of $-0.21 \%$. Furthermore, when the own-firm announcement effect is positive, the rivals' announcement effect for the SS group is lower (more negative) than that for the SC group. The overall results in Table V generally support the theoretical prediction for the role of the strategic competition in explaining the wealth effect of new product announcements on industry rivals: when the market regards the own-firm's new product introduction as value-enhancing, the rivals competing in strategic substitutes experience a less favorable announcement effect than those competing in strategic complements. ${ }^{18}$

\footnotetext{
${ }^{17}$ The conclusions remain unchanged when we use $\pm 0.01 \sim \pm 0.05$ as the cut-off CSM values.

${ }^{18}$ Note that Table V, Panel B, also shows that when the own-firm effect is negative, strategic substitutes interaction elicits a better announcement effect for the rivals.
} 


\section{Concluding Remarks}

This study examines the role of strategic interaction in determining the wealth effect of new product introductions. Announcing firms competing in strategic substitutes have a positive announcement effect, but those competing in strategic complements have an insignificant announcement effect. We also show that the announcement effect of a new product introduction is significantly negatively related to the competitive strategy measure. These results hold after controlling for other variables that could affect the announcement effect. Also, industry rivals generally experience small, but significant, wealth loss when the announcing firm's abnormal return is positive and the competition is in strategic substitutes. The overall evidence suggests that the nature of competitive interaction in an industry is an important consideration in assessing the wealth effect of new product strategies.

\section{References}

Acs, Z. and D. Audretsch, 1988, "Innovation in Large and Small Firms: An Empirical Analysis," American Economic Review 78, 678-690.

Aggarwal, R.K. and A.A. Samwick, 1999, "Executive Compensation, Strategic Competition, and Relative Performance Evaluation: Theory and Evidence,” Journal of Finance 54, 1999-2043.

Atiase, K.R., 1985, "Predisclosure Information, Firm Capitalization, and Security Price Behavior Around Earnings Announcements," Journal of Accounting Research 23, 21-36.

Baldwin, W.L. and G.L. Childs, 1969, "The Fast Second and Rivalry in Research and Development," Southern Economic Journal 36, 18-24.

Barclay, M. and C.G. Smith, 1995a, “The Maturity Structure of Corporate Debt,” Journal of Finance 50, 609-631.

Barclay, M. and C.G. Smith, 1995b, “The Priority Structure of Corporate Liabilities,” Journal of Finance 50, 899-917.

Bulow, J., J. Geanakoplos, and P. Klemperer, 1985, "Multimarket Oligopoly: Strategic Substitutes and Complements," Journal of Political Economy 93, 488-511.

Chan, S.H., J. Martin, and J. Kensinger, 1990, "Corporate Research and Development Expenditures and Share Value,” Journal of Financial Economics 26, 255-276.

Chaney, P., T. Devinney, and R. Winer, 1991, “The Impact of New Product Introductions on the Market Value of Firms," Journal of Business 64, 573-610.

Chauvin, K.W. and M. Hirschey, 1993, “Advertising, R\&D Expenditures and Market Value of the Firm," Financial Management 22, 128-140.

Chen, S.S. and K.W. Ho, 1997, "Market Response to Product-Strategy and Capital-Expenditure Announcements in Singapore: Investment Opportunities and Free Cash Flow," Financial Management 26, 82-88.

Chung, K.H. and S.W. Pruitt, 1994, “Simple Approximation of Tobin's q,” Financial Management 23, 70-74.

D’Aveni, R.A., 1994, Hypercompetition: Managing the Dynamics of Strategic Maneuvering, New York, Free Press.

Deng, Z., B. Lev, and F. Narin, 1999, "Science and Technology as Predictors of Stock Performance," Financial Analysts Journal 55, 20-32.

Denis, D.J., 1994, "Investment Opportunities and the Market Reaction to Equity Offerings," Journal of Financial and Quantitative Analysis 29, 159-177.

Dodd, P. and J. Warner, 1983, “On Corporate Governance: A Study of Proxy Contests,” Journal of Financial Economics 11, 401-438.

Hall, B.H., 1999, “Innovation and Market Value,” National Bureau of Economic Research, Working Paper 6984. 
Hall, B.H., A.B. Jaffe, and M. Trajtenberg, 2000, "Market Value and Patent Citations: A First Look," National Bureau of Economic Research, Working Paper 7741.

Hall, B.H., A.B. Jaffe, and M. Trajtenberg, 2001a, "The NBER Patent Citations Data File," UC Berkeley, Brandeis University, Tel Aviv University, and National Bureau of Economic Research.

Hall, B.H., A.B. Jaffe, and M. Trajtenberg, 2001b, "The NBER Patent Citations Data File: Lessons, Insights and Methodological Tools," National Bureau of Economic Research, Working Paper 8498.

Hendricks, K. and V. Singhal, 1997, "Delays in New Product Introductions and the Market Value of Firm: The Consequences of Being Late to the Market," Management Science 43, 422-436.

Holderness, C.G., R.S. Kroszner, and D.P. Sheehan, 1999, "Were the Good Old Days that Good? Changes in Managerial Stock Ownership Since the Great Depression," Journal of Finance 54, 435-469.

Jensen, M., 1986, "Agency Costs of Free Cash Flow, Corporate Finance, and Takeovers," American Economic Review 76, 323-329.

Kasanen, E., 1993, “Creating Value by Spawning Investment Opportunities," Financial Management 22, 251-258.

Kelm, K.M., V.K. Narayanan, and G.E. Pinches, 1995, "Shareholder Value Creation During R\&D Innovation and Commercialization Stages," Academy of Management Journal 38, 770-786.

Kleinschmidt, E.J. and R.G. Cooper, 1991, "The Impact of Product Innovativeness on Performance," Journal of Product Innovation Management 8, 240-251.

Lang, L., R. Stulz, and R. Walkling, 1989, "Managerial Performance, Tobin's $q$, and the Gains from Successful Takeovers," Journal of Financial Economics 24, 315-335.

Lang, L., R. Stulz, and R. Walkling, 1991, "A Test of the Free Cash Flow Hypothesis: The Case of Bidder Returns," Journal of Financial Economics 29, 315-335.

Lee, H., 1995, "Shareholder Wealth Effects of New Product Rivalry: First Movers, Second Movers, and Laggards," University of Maryland, Ph.D. Thesis.

Lehn, K. and A. Poulsen, 1989, "Free Cash Flow and Stockholder Gains in Going Private Transactions," Journal of Finance 44, 771-787.

Mansfield, E., M. Schwartz, and S. Wagner, 1981, "Imitation Costs and Patents: An Empirical Study," Economic Journal 91, 907-918.

McGahan, A.M. and B.S. Silverman, 2001, "How Does Innovative Activity Change as Industries Mature?" International Journal of Industrial Organization 19, 1141-1160.

Perfect, S.B. and K.W. Wiles, 1994, “Alternative Constructions of Tobin's q: An Empirical Comparison," Journal of Empirical Finance 1, 313-341.

Porter, M.E., 1980, Competitive Strategy, New York, Free Press.

Silverman, B.S., 1999, "Technological Resources and the Direction of Corporate Diversification: Toward an Integration of the Resource-Based View and Transaction Cost Economics," Management Science 45, 1109-1124.

Smit, H.T.J. and L.A. Ankum, 1993, "A Real Options and Game-Theoretic Approach to Corporate Investment Strategy Under Competition," Financial Management 22, 241-250.

Sundaram, A.K., T.A. John, and K. John, 1996, "An Empirical Analysis of Strategic Competition and Firm Values: The Case of R\&D Competition," Journal of Financial Economics 40, 459-486.

Szewczyk, S., G. Tsetsekos, and Z. Zantout, 1996, "The Valuation of Corporate R\&D Expenditures: Evidence From Investment Opportunities and Free Cash Flow," Financial Management 25, 105-110.

White, H., 1980, "A Heteroskedasticity-Consistent Covariance Matrix Estimator and a Direct Test for Heteroskedasticity," Econometrica 48, 817-838.

Woolridge, R., 1988, "Competitive Decline and Corporate Restructuring: Is a Myopic Stock Market to Blame?" Journal of Applied Corporate Finance 1, 26-36. 